\title{
THE WIFE OF MANOAH, THE MOTHER OF SAMSON
}

\author{
Magdel le Roux \\ University of South Africa \\ P O Box 392, UNISA 0003 \\ E-mail: Lrouxm1@unisa.ac.za
}

(Received 21/04/2016; accepted 06/07/2016)

\begin{abstract}
The last account of the judges is that of Samson (Judges 13-16). This account has all the elements of a blockbuster. All the indications are that Samson would be an extraordinary person. And yet, even though Samson may be regarded as some sort of hero, the story suggests that Samson was also the weakest or most ineffective of the judges. Tension is created through the juxtaposition of "ideal" and "non-ideal" bodies. An alternative ideology, as a hidden polemic, is concealed in the account. As in the case of Achsah (Judges 1:11-15) and Deborah (Judges 4-5), the nameless wife of Manoah (the mother of Samson) serves as an illustration of "countercultural rhetoric" as a hidden polemic.
\end{abstract}

\section{INTRODUCTION}

In the dominant cultural ideology of the Israelite tribes, ideal, whole bodies were those of male Israelite soldiers without any defects. This is the image that comes to mind when one first reads about the strong man, Samson, although in time one becomes more aware of his weaknesses than his strengths. These accounts (Judges 14-16) are full of violence and of Samson's personal revenge, but they also describe his weakness for women. In the case of Samson, an ideal male body develops into an "unwhole body" in that an aesthetic element is added to the story: God favours Samson despite his disobedience (Chs 14-16). It is remarkable how little patience the Angel of the LORD has with Samson's father, Manoah (Ch. 13), compared with the endless patience that the Angel of the LORD shows to Samson. Sternberg (1987:44) believes that this is a "narrative technique" to describe the involvement of God and to justify a person's actions. The opposite often happens, too, namely that an unwhole body is portrayed positively, but in time develops into an ideal body that is eventually portrayed negatively (e.g., cf. Judges 6-8 in the case of Gideon and Judges 11 in the case of Jephthah; van der Merwe \& Coetzee 2009:679). 
The Samson saga features three accounts. The first deals with the announcement of his birth (Ch. 13), and the other two with his experiences with heathen women (Chs 14-16). It is particularly in the first account (Judges 13) that a countercultural rhetoric, as hidden polemic, comes to the fore. Contrary to the expected cultural ideology, a woman - a non-ideal, unwhole body - is positively portrayed and plays a prominent role in the introductory account of Samson's life. The narrator's literary portrayal of the different "bodies" in the story therefore differs from the dominant "body ideology" of the intended audience (Amit 2000:122-129). What is the purpose of challenging or polemicising the existing cultural perception or ideology? Or why is it not mentioned explicitly?

There are two types of women in the Samson story (and elsewhere), in particular: the good (safe) women and the bad (dangerous) women (Exum 1995:78). The good women are usually placed on a pedestal, as a mother or a virgin, and their non-sexual role is idealised. The bad woman's sexuality is of prime importance and is blamed for the man's desires and urges ${ }^{1}$ (Exum 1995:78). From a literary viewpoint - the femme fatale described in Proverbs 7 - the man follows the woman like a lamb to the slaughter. Proverbs 1-9 (also Eccl 7:26) warn against the dangers of the "foreign woman" and this theme is repeated throughout Judges 14 and 15 (cf. 14:3 and 15:8). Delilah and other women in Samson's life are often referred to as "immoral", bad women (which some probably were), but Samson is never described in these terms (i.e., as "immoral" or "bad").

Matthews, Levinson \& Frymer (2004:20) point out that in Nippur, two opposing stereotypes of women also functioned in the "culpable homicide trial": the one was that women are "weak and easily intimidated" and the other was that women are "inherently dangerous and under suspicion". Accompanying these perceptions (as described above) was the belief that because women are "weak" and "under suspicion", men were the natural soldiers - not women. Therefore, the ideal body was the male Israelite soldier or warrior, and women, crippled or deformed people and

1 This stereotype still exists today in most patriarchal societies. 
foreigners were unwhole or had non-ideal bodies (cf. Nah 3:13).

Samson's mother (Judges 13) belongs to the category of "good women". She is portrayed more positively than her husband, Manoah, probably because she acts in accordance with the dominant cultural ideology: she poses no threat to him; she does nothing on her own - she consults with her husband if something unusual occurs; she does not challenge him or his position or authority, and she also does not ask unnecessary questions. According to Exum (1983:3-45), this is the typical image of a woman who fits in with a patriarchal society. According to that tradition, women cannot act independently, assume leadership positions, make decisions, own land or serve as reliable witnesses.

Notwithstanding the above, the role of women ${ }^{2}$ (non-ideal, unwhole bodies) may be regarded as a binding factor or framework in the book of Judges. For example, compare the role of Deborah and Jael (Judges 4-5); the accounts of Abimelech in Judges 9; that of Jephthah in Judges 11, and that of Micah's mother in Judges 17:1-6. The latter three accounts are also bound together by the theme of motherhood. But it is especially in Judges 13 that the theme of motherhood is central. The theme of the goddess Anatu, who was barren, is well known in both Ugarit and certain parts of Egypt (KTU 1.13, in te Velde 1967:28-29; cf. Marsman 2003:210). ${ }^{3}$ Manoah's nameless wife, ${ }^{4}$ later Samson's nameless mother (a non-ideal body), who has no status in the dominant cultural ideology (because she is a woman, and even more so because she is barren), shows unprecedented spiritual insight (Ackermann 1998:184-185).

As expected, little information is given about Manoah's wife as a person and the narrator focuses on her role as "mother", just as Jephthah's daughter is also remembered as a "daughter" (Ch. 11; Exum 1995:79). As explained previously, motherhood was one of women's greatest rewards in the dominant cultural ideology.

2 I am not even referring to the role the three "Philistine" women play in Samson's life.

3 "The Instruction of Ankhsheshonqy" emphasises that a mother is highly esteemed. The mother-goddesses held the highest position in the pantheons of the ancient Near East (Krebernik 1993-1997:502-516; Del Olmo Lete 1981:49-62).

4 Midrash Rab. Num. Naso 10 and Bava Batra 91a state that Hazelelponi (also spelled Hazzelelponi or Z'llpunith or Zlelponith), the daughter of Etam, was the mother of Samson, see $1 \mathrm{Chr} 4: 3$. 
It was one of the few roles by means of which a woman could gain status in society and one that offered her the possibility of being released from her undesirable position in society. Not one of the women with whom Samson was sexually involved became a mother (according to the account, or as far as we know) - and they were therefore not "redeemable" according to the standards of that ideology.

The account contains all the indications (Judges 13) that Samson would become an exceptional person: (1) the Angel's appearance and announcement to the barren woman, (2) the vow of Naziriteship, and (3) the blessing of Yahweh that accompanies the "Spirit of the LORD" (verses 24-25). Although Samson may be regarded as some sort of hero, his story is told in such a way as to suggest that he was actually the weakest or most ineffective of all the judges. Manoah, Samson's father, is also represented as being ignorant, unwise and dependent on his wife's knowledge and spiritual interpretation. The problem is that it is easy to ignore the fact that the two ideal male Israelites (Manoah and Samson) do not meet the expectations of a hero and that Samson's mother is actually the heroine in the story (McCann 2002:97).

It is possible that Chapter 13 originated with a female circle of writers (Brettler 2002:49), which would explain why the chapter is so irregular. It has no part in the "male elite authorship" that is so typical of the rest of the Bible. Canonisation was a complex, inclusive process that allowed a wide variety of literature to be incorporated into the text of the Bible (Davies 1998). We find a similar case in the book of Ruth (Brenner \& van Dijk-Hemmes 1996:105-107). It is remarkable how different the "female voice" is from the rest of the account in chapters 14-16. Perhaps this version of Samson's background was the most colourful of all the available accounts and the compiler/s of the book thought that it would fit in with the rest of the account fairly easily (Brettler 2002:49).

However, few readers notice the message hidden in Chapter 13 and focus excessively on the sensational accounts that follow in chapters 14-16. A sociorhetorical approach makes it possible to identify rhetorical techniques that the writer uses to highlight social relations, regulations and ideologies in the text, which relate to ideal and non-ideal bodies and their prescribed functions in society (van der Merwe 
2009:678; cf. LaCocque 1990:23, 28). ${ }^{5}$ This approach is an authoritative aid to reveal certain parts and it offers new possibilities for interpretation. A study of the literary techniques that are used by the writers ${ }^{6}$ as countercultural rhetoric forms the basis for a discussion of the countercultural rhetoric as hidden polemic. Just as in the case of Achsah (1:11-15; cf. le Roux 2015:503-521) and in other parts of the book of Judges, the narrator subtly criticises the customs and traditions of the society in which they live.

\section{CONTEXT OF THE ACCOUNT IN JUDGES 13}

The birth of Samson, as with many other heroes, was announced and accomplished supernaturally. As mentioned previously, all the indications are that he would be a hero - someone specially appointed by God as judge to free his people (Israelite tribes) from their oppressors, the Philistines.

Apart from the role of his mother, the wife of Manoah, the story of Samson revolves primarily around three "Philistine" women - the woman from Timnah (14:115:20), the prostitute in the Philistine city of Gaza (16:1-3), and Delilah, the only one who is named (16:4-31). However, it is not an established fact that all three of the women were Philistines; the text says only that Samson's wife from Timnah was a Philistine, so the others might well have been Israelites. Delilah, for example, has a Hebrew name and she lived on the border of the Israelite and Philistine territories (Exum 1995:80). It is often assumed that she was a Philistine simply because she surrendered Samson to the Philistines (Judges 16).

The last part of Chapter 16 makes it clear that Judges 13-16 has a complex editorial history and most likely originated from various sources that were later combined. Despite the fact that each unit has a different structure and tries to make a different point, the units still belong together in more than one sense (Brettler

5 The research of van der Merwe (2009) is used extensively in this regard.

6 The writer will usually be referred to, without ignoring that the book passed through the hands of different writers and/or editors. It is also possible that only the narrator of the account is speaking. 
2002:58). Brettler shows how the wife from Timnah, with her weeping behaviour, anticipates Delilah. The number 3000 occurs in both 15:11 and 16:27. Prayer also plays an important role in 13:8 and at the end of both chapters 15 and 16 (cf. Exum 1983:3-45). The attempt by the Judeans to control Samson by tying him up with new ropes (15:13) corresponds with Delilah's attempts in 16:11-12. Chapters 14 and 16 begin in the same way, with Samson going somewhere and then "seeing" a woman. The similarities may be coincidental or they may have been created after combining the accounts (Brettler 2002:59). Everything revolves around Samson's own needs and desires - his mission as judge to free his people from the Philistines is quickly forgotten.

Another theme that comes to the fore in the narrative (Judges 13-16) is the fact that Samson does not fulfil his Nazirite vow (Blenkinsopp 1963:65-76; Crenshaw 1978). Chapters 13 and 16 refer to this explicitly, while chapters $14-15$ refer more implicitly to ways in which Samson breaks his vow: he drinks wine at parties and makes himself unclean by touching dead bodies and carcasses. Because the Samson saga has a complex editorial history (or a narrator who created a composition from available material), it is very difficult to isolate a single theme. Brettler (2002:60) reckons that the Samson cycle represents an editorial model that is not well presented from a thematic and stylistic point of view. Hamlin (1990:126) sums up the Samson saga as follows:

[It is a real] human drama full of passion and love that is marred by fear, aggression and bribery (Judg 14:15; 16:5); full of insults and revenge $(14: 20 ; 15: 3,7,10)$; burning fields and glowing corpses (15:4-6); of a hero who 'saw' beautiful women $(14: 1 ; 16: 1)$, but was 'blind' to the consequences of his foolish love affairs (16:21); of a 'superman' who could carry a city gate $40 \mathrm{~km}$ up a mountain (16:3), could break unbreakable ropes on four occasions, but not the ropes of a web of love; of a proud champion who was humiliated and praised on two occasions, one for life (15:19) and one for death. Thus he achieved his own goal in 
life $(16: 28,30)$ and carried out the mysterious work of God, which was not 'seen' by his own people (especially his father) (13:16; 14:4; author's inverted commas).

Samson (Chs 14-16) stands in sharp contrast to the expectations created in Chapter 13, but also to Othniel, the model judge of Judah, for whom everything worked out well (3:7-11; cf. also Deborah in chs. 4-5). The Jewish tradition regards Samson as the most worthless judge, the only one to fall into the hands of the enemy and to die in captivity (Hamlin 1990:127).

\section{COUNTERCULTURAL RHETORIC AS A HIDDEN POLEMIC}

Tension and irony are subtly created in the book of Judges in order to compare opposing systems or ideologies and thereby create rhetoric (van der Merwe 2009). A countercultural rhetoric is thus used to indicate an alternative ideology about differently functioning bodies in society.

Amit (2000:3, 94-95) shows that the text contains three types of polemic, namely explicit, implicit and hidden polemic. An example of explicit polemic is where the author pertinently points out that God "handed [his children] over to the enemy" when they were disobedient and followed false gods (Judges 2:14; 3:8; 13:1; van der Merwe \& Coetzee 2009:677-694). Implicit polemic is when the author indirectly refers to a matter, for example when God immediately responded to the Israelites' cry for help, without stating explicitly that God is merciful. Bible writers or narrators use hidden polemic subtly to comment on reality and the functioning thereof. A hidden polemic in the text can be tested on the basis of the following criteria (Amit 2000:96; van der Merwe \& Coetzee 2009:681):

- there is no explicit reference to the polemic that the writer rejects or encourages;

- the writer uses a few signs or techniques in the text to draw the attention of the reader to the polemic;

- there are other Bible texts that could confirm the existence of the polemic on the same subject; and 
- possible references or interpretations of the hidden polemic exist in exegetical and extra-biblical texts.

It is not explicitly stated, but the writer uses different techniques to direct the reader's attention to the specific polemic (van der Merwe \& Coetzee 2009:681). In Judges 13, it is easy to overlook the hidden polemic because other explicit and implicit polemics also convey important messages. In the past, commentators and other academics have often been blinded by the explicit and implicit messages (promonarchal, pro-Judah, etc.). The question is, why is the message or polemic hidden in the text? It may be a persuasive technique that the writer uses, but by the writer's silence and use of certain techniques in the text, the reader is constantly reminded and encouraged to find the hidden polemic in the text by himself or herself (Amit 2000:97). Another possibility is that the writer is simply not permitted to express a critical opinion about certain things in the dominant culture or to comment on them (Amit 2000:97). As explained above, a hidden polemic was therefore an effective way in which Bible writers could subtly comment on their society. Van der Merwe and Coetzee (2009:682) are of the opinion that the more controversial the "alternative body ideology" proposed, the more hidden the polemic.

\section{JUDGES 13 AS AN EXAMPLE OF “COUNTERCULTURAL IDEOLOGY” AS A HIDDEN POLEMIC}

Judges 13:1 begins by explicitly stating that the children of Israel had again done what was bad in the eyes of the LORD, thus explaining why a judge was needed - the Philistine oppression. Judges 13:2-25 is an independent unit that tells of Samson's birth. This is accompanied by an announcement that focuses on Samson's miraculous birth and his status as a Nazirite (Alter 1990:115-130; Amit 1999:292-293). The theme of a barren couple is well known in the Bible. Readers who are familiar with this type of Bible account will know that the child that is born as a result of Yahweh's intervention will be very special. Therefore, the account begins with a well-known theme to create certain expectations in the listener or reader (Marais 2001:44). 
There are three role-players in the account about the birth announcement of Samson in Judges 12: Manoah, his wife and the "Angel of the LORD". This part is an illustration of the dominant Israeli ideology-culture - Samson's father, Manoah (the ideal male Israelite/body), is named fifteen times in this chapter, ${ }^{7}$ compared with his nameless wife (13:2). The observant reader will already be questioning this. It is typical of the cultural ideology that a woman exists by the grace of her husband - she is called "the wife of Manoah". The woman in this story is not only nameless, but also barren. ${ }^{8}$

A woman's "failure" to have children was often interpreted as punishment from God, by means of which she suffered and brought reproach on her husband within the community (van der Merwe \& Coetzee 2009:683). A woman's standing and respect in society was largely related to the birth of her first child - especially if it was a boy (Gen 16:4; 29:31). Without this, she was not worth much.

Furthermore, according to the cultural ideology, a man could divorce his wife if he discovered that she was barren - depending on the interpretation of Deuteronomy 24:1-4 (Matthews, Levinson \& Frymer-Kensky 2004:111). Also, according to the cuneiform law (LH 138, 141, in Roth 1995), a man could divorce his wife if she could not bear children, but at least he had to pay her compensation. This was usually the equivalent of her dowry (Roth 1995).

In the light of the traditional position of the woman in society, the juxtaposition of Manoah (the ideal male Israelite, "whole body"), and his nameless wife (non-ideal, "unwhole body") creates tension in the account, especially if the non-ideal body shows insight into situations, while the ideal male body is presented as being uninformed and even foolish. This technique should alert the reader that the writer may wish to convey a message in a subtle manner.

In 13:1 we also find an abridged framework (of disobedience, oppression and results) into which the rest of the accounts in the book are woven (cf. 2:11, 14;3:7-8;

7 It is remarkable that Manoah is not mentioned by name in chapters 14 and 15 . The messenger of Yahweh, who plays a central role in Chapter 13, is also absent from Chapter 14. It appears as if 13:2-24 should be seen as a separate unit that is rounded off with verse 25, namely that the Spirit of Yahweh "started to impel him" (Brettler 2002:43).

8 According to the cultural ideology, only the woman could be barren, never the man. 
$4: 1-2 ; 6: 1 ; 10: 7-8)$. The Israelites had been delivered into the hands of the Philistines for "forty years". It is remarkable that at no time in this account do the Israelites express remorse or call to God for help. However, God has not abandoned his unfaithful "nation"” (McCann 2002:95). Although the account does not explicitly say that God will provide a deliverer for the "nation", it does relate, starting in verse 2, that a child will be born who will "begin to save the Israelites from the Philistines" (13:25). ${ }^{10}$ As mentioned previously, God's mercy is thus suggested implicitly.

Although the narrator regards the Philistines as oppressors, the Israelites (and especially Samson) obviously do not. Later in the account, they appear to be quite happy that "the Philistines are ruling over them" (15:11; McCann 2002:94). This is not a good sign. At least Gideon acknowledged that "the LORD will rule over you" (8:23), even though his later actions contradicted this, and Jephthah at least acknowledged that the LORD gives the victory (11:9).

At this stage it seems as if the Israelites no longer have any idea that God is ruling over them - they have reached an all-time low in their relationship with Yahweh (McCann 2002:94). They are even prepared to surrender Samson, their potential "deliverer", into the hands of the Philistines (Judges 15:1-13). ${ }^{11}$ It is against this background of the spiritual low in the lives of the "children of Israel" that the spiritual

9 It was usually only when the Israelites were suffering that they turned to the LORD for help, but this time they failed to do so - which indicates the downward trend that permeates the book. The oppression was not God's doing (although He allowed it), but, according to the account, was the direct result of the fact that they had ignored God, their true leader and redeemer (Lucas et al. 1984:34). God punished them, but they also punished themselves through the wrong choices that they made.

10 Because of Samson's unfaithfulness, their deliverance would not be complete. The problem was not just the people's unfaithfulness, but also the unfaithfulness of the "judge". Even though he did not agree with the oppression by the Philistines, his weakness for women was so overwhelming that it blinded him to his godly commission. Samson would later call to the LORD for help (15:18-20), but the power that He gave him led to his own downfall and not really to the deliverance of the Israelites.

11 The Philistines are mentioned only indirectly in 3:31 and 10:6-7. For example, there is no mention of the Philistines in Chapter 1, which might indicate the age of Chapter 1 . The Philistines had probably not yet occupied the fertile coastal plain (Shephelah) when these events were recorded. The neighbours with whom the Israelites eventually committed the most "sins" were the Philistines. 
insight of Samson's mother (a non-ideal body) is so remarkable.

Samson's parents were from the small town of Zorah, on the border between Dan and Judah, on the coastal plain west of Jerusalem (Cundall 1968:156). The area where the Danites ${ }^{12}$ were supposed to settle was situated between Ephraim in the north, Judah in the south and Benjamin in the east. Joshua 19:40-48 describes the region, but unfortunately gives no details of the borders and the inhabitants of the area (Soggin 1981:226). The only information available about the tribal allotment of Dan is the list of cities that we discover from the book of Joshua and from the Samson account. We know only that the tribe of Dan tried, with difficulty, to settle in its tribal allotment west of Jerusalem. In fact, as a result of the oppression of the Amorites (1:35), the Danites later moved northwest and established themselves unlawfully (outside the "Promised Land") at the foot of Mount Hermon (cf. Ch. 18; cf. 5:17; Hermann 1981:92). However, Soggin (1981:227) suggests that the "Amorites" were not the problem in the area, but rather the Philistines.

As mentioned above, the Israelites do not ask God for help, but the LORD, of his own volition, decides to cause Samson's miraculous birth. The LORD makes this possible by allowing a barren woman to bear a son. The theme of childlessness often occurs in the Old Testament (cf. e.g., Hanna versus Penina in 1 Sam 1-2).

The "Angel of the LORD""13 appears to the nameless woman (non-ideal body)

12 At this stage, it appears that the Danites were already planning to settle in the north, which explains why some of the remaining Danites set up camps in the area (cf. the place name magane-dan in 13:25). It is noteworthy that the Danites are not referred to as a "tribe" in the account, but rather as a generation or family (mišpahāh). Although they were one of the original tribes of Israel, here they are simply called a generation or family (Klein 1988:106). This may be one reason why Dan is not referred to as one of the 12 tribes in Revelation (7:4-8). Be that as it may, the fact is that after Deborah, most of the judges were identified by their families and not by their tribal names (Klein 1988:106). This might indicate the period when the accounts were combined (period of exile?).

13 We usually assume that the "Angel of the LORD" was the LORD himself. Despite their unenviable position in society, special appearances by God were usually made to women, and often to barren women (cf. Hagar, Gen 16; 21:8-21; Sarah, Gen 18:9-15; Rebekah, Gen 25:21-28; Rachel, Gen 29:31; Hannah, 1 Sam 1:2, and Mary and Elizabeth in the New Testament, Luke 1; 2; Niditch 1997:39). The appearance of God in Judges 6:11-24 strongly parallels that in Chapter 13. Each of these announcements, except the one about Isaac (Gen 17:16-21; 18:10-15) occured when the Angel of the LORD first appeared to the mother and then, later, to the father. This marked the beginning of a special relationship between 
while she is sitting alone in the field and announces that she will become pregnant and give birth to a son (Judges 13:3). He gives her instructions as to how she should take care of herself, then confirms that she is already pregnant and indicates how the son that will be born should live $(13: 4,5)$. He also announces that the boy would just "start" to deliver the Israelites from the Philistines.

Contrary to the traditional expectations, Manoah's nameless wife is important enough to God to receive the divine message (Niditch 1990:143). It is clear that she plays a central role in the events and it is to her that the Angel appears twice $(13: 3,9)$. She is not properly introduced, we do not even know her name (Harris et al. 2000:239), and yet the Angel appears to her. This surprising development speaks volumes about God's evaluation of men and women as equals and, at the same time, it hints at the possibility of further hidden elements of surprise in the account (Harris et al. 2000:239). In both cases in which the Angel appears to her, the wife of Manoah is sitting alone in the field ${ }^{14}$ - another unusual, dangerous situation for any woman (contrary to the social and cultural norms). In this regard, Manoah's wife exceeds her social boundaries (cf. van der Merwe \& Coetzee 2009:683). ${ }^{15}$ According to Berquist (2002:42), a "body" that oversteps its boundaries is unclean, and everything that comes into contact with it also becomes unclean (cf. Lev 15:13-18).

We do not know much about the messenger in this appearance because the woman's pregnancy is announced by an equally nameless Angel of the LORD. The woman shows unprecedented faith and insight by acknowledging the "Angel" as "a man of God", not asking his name and also not questioning the message.

As already mentioned, to be a woman in the dominant culture was one thing, but being barren brought great reproach on the household. We can anticipate what the Angel's message would be. ${ }^{16}$

Yahweh and the child (Matthews 2004:139). This relationship usually meant that God would direct the activities and life of the person involved.

14 The mention of local topograhical landmarks is a striking feature of the book (cf. 21:19; Amit 2000:112)

15 Compare Achsah (Judges 1); Deborah (Judges 4-5) and the prophetess Huldah, who was known for her actions in 2 Kings 22:14-20 (Meyers 1998:256; cf. Frymer-Kensky 2006).

16 The divine appearance often happens against the background of a male hero. Signs of the 
Therefore, the first thing that the Angel of the LORD comes to tell the nameless woman is that she will become pregnant. Up until the time of the announcement, she is barren, alone in the field and rather inconspicuous. At this point, her situation changes, she is no longer "nameless" (in a figurative sense). The fact that she is going to become pregnant is confirmed in 13:5 and 7. The Angel announces that a miracle will take place, but he also says that she will give birth to a son - an even greater miracle (cf. Luke 1:31).

In verse 3 , the woman is not yet pregnant. In verse 5 , the woman is already pregnant - the original reads (verse 5): "you are pregnant" (hannach harah). Most translations actually obscure the fundamental fact that is emphasised in the chapter, namely that the messenger (Angel) of Yahweh caused the miracle to happen (Brettler 2002:45). The miracle has already happened and the Angel confirms that it will be a son (Berlin 1983:91-94). Manoah's wife separates herself and thus hears the "voice of the LORD" and makes herself available to serve Yahweh (cf. also Deborah in Judges 4).

The Angel warns the woman to take good care of herself during her pregnancy and gives her a list of instructions to follow (Judges 13:4, 5). She has to create Nazirite conditions for the child by abstaining from wine or strong alcohol and not eating anything unclean, just as he would do. The vow is then repeated.

The only Nazirite instruction ${ }^{17}$ that would govern this special child's life is conveyed to the woman: he may never shave his hair. ${ }^{18}$ This is also the only

future importance of the child include: the childlessness of the mother, or the threat to the child's life; a specific instruction to the son that would be born; a sacrifice that is made and the assurance given that Yahweh would bless the child (Niditch 1997:39).

17 The Hebrew word nazir means to be "separated" or "consecrated" (NRSV, RV). In Numbers 6:1-5, we find the expanded list of instructions for such a person: As a sign of his special, charismatic status, his hair may not be shaved; he may not consume any alcoholic beverage and he may not touch anything unclean. Unlike in the case of the priesthood, Samson's form of "sacredness" was not inherited (Niditch 1990:143). To be sanctified at a certain level means to be "separated" from the social and cultural life (Niditch 1990:143). That was what the Israelites needed so desperately at that time, one who was separated for the service of Yahweh and capable of leading others in the right direction (McCann 2002:98). It is remarkable that God was able to achieve anything at all through a character like Samson (McCann 2002:93). This is a common theme; compare Rahab, the prostitute living on Jericho's wall, who helped to save Israel and became part of the genealogy in 
instruction that Samson upholds to the end (until Delilah puts a stop to it). This shows that the child would be consecrated to God (cf. Luke 1:15), in other words, he would be a Nazirite. The MT says that he would be nezir elohim, in other words, "a Nazirite of God". 19

Usually a person makes a vow to live as a Nazirite, but in this case the Angel of the LORD tells Samson's mother that she and her son will be consecrated to God compare Judges 13:4-7 (Ackermann 1998:114). This section implicitly shows that both men and women can take a vow to be a Nazirite. The Hebrew Bible contains no examples of women who had to live as Nazirites their entire lives, but there are examples of temporary Nazirites. Thus Samson's mother was also expected to observe the Nazirite regulations during her pregnancy (13:4 above; cf. also Hannah in 1 Sam 1; Ackermann 1998:114).

The second announcement (see verse 3 above) of the Angel of the LORD to the woman is that Samson would "start" (verse 5) to break the Philistines' power. It is almost as though the narrator knew that Samson would not succeed in completely overthrowing the Philistines, hence the remark that he would simply "start" to do so. That would finally happen only in the time of Saul and David (cf. 2 Sam8:1)

In light of the remarkable role played by the wife of Manoah, it is strange that "the woman" remains nameless (cf. also other nameless women in the book of Judges: Jephthah's daughter [11:29-40], the woman who crushed Abimelech's skull [Ch. 9] and the Levite's concubine [Ch. 19]).

In the latter cases, the omission of the women's names is probably to show that they are marginalised and victims of their circumstances, but this cannot be the case

Matthew 1:5.

18 Long hair was typical of epic soldiers in the Hebrew Bible (such as Absalom; Niditch 1990:144).

19 God's faithfulness in attempting to save his "nation" is clear, but Samson's unfaithfulness is shocking. Later Samson manages to break just about every aspect of the Nazirite vow to God: he drinks alcohol (14:5,10; cf. Num 6:3); he touches the carcass of a dead animal (14:8; cf. Num 6:6-8); and, finally, he allows his hair to be shaved (16:15-22; cf. Num 6:56; McCann 2002:99). Furthermore, he is constantly in contact with the inhabitants of the land, which is forbidden $(2: 1-5 ; 3: 6)$, yet the only time God's Spirit appears to leave him is when his hair is shaved off. 
with Samson's mother (McCann 2002:95). According to Alter (1990:51), the namelessness of Samson's mother is used purposefully by referring to her as "the woman" every time she speaks or acts. He opines that Chapter 13 (implicitly; author's insertion) anticipates other references to women in the Samson account effectively (cf. 14:1-2; 16:1). The namelessness of Samson's mother can also be read in the light of the Angel's refusal to give his own name. This emphasises the intimacy between the Angel and Samson's mother and helps to accentuate her central role in the account (Reinhartz 1998:29). The Angel thus implicitly identifies with the nameless woman.

The fact that Samson's mother is the real heroine in the account is actually just another riddle (hidden) in the account (of Samson), which already contains many other riddles. In other words, the question is whether the reader of Judges 13-16 will have the insight to see that of all the characters in Judges 13-16, a nameless woman has a model relationship with Yahweh. This is what he desires for all his children in the book of Judges, namely obedience to his regulations, faith and a lifestyle that would distinguish them from other nations (Reinhartz 1998:29).

The woman immediately recognises "the man of God" (13:6) and knows that he has come in peace to bring a blessing. In line with the cultural ideology, she is careful to express her own opinion by simply telling her husband that he looked like "an Angel of the LORD" and like someone with authority. Manoah (later) treats him as just a special visitor (verses 8,17 ), nothing more. The "woman" is thus portrayed in contrast to Manoah (the ideal male Israelite), who does not immediately realise who they are dealing with and is dependent on his wife for guidance and interpretation of the events. In this respect, he is passive and she is active, contrary to the conventional expectation of the intended readers/listeners in terms of what the roles of these bodies should be.

Against the background of the cultural ideology, the woman probably knows that her husband will first want all the information before he can make a decision and, therefore, she simply states up front that she did not ask him (the Angel) all the questions to which she knew he (her husband) would want the answers. She does not know where the person came from, or what his name is (13:6). 
The woman's repetition of the instructions of the Angel emphasise the importance of the unborn son's separateness (sacredness). However, she does not repeat exactly what the Angel said. She repeats everything (see verses 3-5), except that his hair may not be shaved and that he would deliver the Israelites from the Philistines (Harris et al. 2000:240).

She adds the part "from birth until the day of his death" (13:7), or the narrator attributes those words to her in order to show how the rest of the account would unfold. Perhaps the mother of the child has a premonition about his life or realises that the responsibility resting on him will require devotion until the end of his life. It is striking that the text contains no expression of joy at the, possibly, long-awaited pregnancy. But perhaps it is just not mentioned.

As expected in the dominant cultural rhetoric, the wife comes to tell her husband, Manoah, what happened - after the Angel of the LORD appears to her (Judges 13:6). Because a woman's testimony was not worth much in the dominant culture, she was hesitant to approach her husband to tell him what had happened. Her insight into what had happened is reflected in her interaction with her husband (Niditch 1990:144).

Manoah (the ideal male Israelite) does not completely believe the story his wife (the non-ideal female body) relates to him or is not satisfied with the information. Within the dominant cultural ideology, it is understandable that he is uncertain and wants to obtain more information (Niditch 1997:39). He himself would rather hear it from the LORD - if it really originated with the LORD. Therefore, Manoah prays to ask the LORD to send the "man of God" again to both of them, so that they will know what they must do with the son (13:8). Manoah also refers to the Angel as the "man of God" on account of what his wife has told him. He thus gives her the benefit of the doubt.

The LORD hears Manoah's prayer for more information, but the messenger does not appear to both of them, as requested. This, in my opinion, shows a touch of humour: it is clearly stated that the Angel of God again appears only to the woman. And it also expressly says that this occurs when she is in the field and her husband, Manoah, is not with her. Even though Manoah asked so nicely for the Angel to appear 
to both of them, it does not happen that way. It seems as if the Angel is a little wilful, but this probably reveals a hidden polemic. Perhaps it is precisely because she separates herself - and is sitting alone in the field - that the Angel appears to her again. In contrast to most Bible accounts, the woman in this case is portrayed as taking the lead - which she actually does later on (13:23). This makes one wonder if Manoah would have ever seen the Angel if it had not been for his wife (Exum 1980:43-59).

Before the Angel can say anything, the woman runs to call her husband - he can now hear for himself what the man has to say (13:10). In verse 6 , she says that "the man of God" appeared to her. In verse 10, she refers only to "the man". As we might expect of her, she wants to let her husband decide for himself who "the man" is.

According to the account, Manoah gets up and goes with his wife so that he can hear for himself what the messenger has to say (13:11). He starts asking questions: first, before saying anything else, he wants to know whether this is the same man who spoke to "the woman" - he does not refer to her as his wife. He thus questions his wife's story and her judgement (Niditch 1997:40). "The man" confirms that it was indeed him with a simple "yes".

If what "the man" said to his wife is true, Manoah also wants to know more about the special child. How will the boy live and what will his work be (13:11)? This relates to the request in his prayer (13:8).

We can again sense a "wilfulness" in the Angel (13:13): his answer implies - go and ask your wife; I have already spoken to her and told her everything. The Angel thus implicitly encourages Manaoh to accept what his wife has already told him (McCann 2002:97) and that a woman can be a reliable witness. ${ }^{20}$ The intended reader/listener is now being further persuaded that a non-ideal body (differently functioning body) is equal in value and definitely beneficial in the corporate body - in contrast with the expected ideal male body.

He thus confirms that he has already given the woman the instructions regarding the child. In this dominant cultural ideology, it would simply be easier for Manoah to

20 After his resurrection Jesus trusted a woman to be the first witness. 
say that he himself had heard the message from the Angel and not that he had heard it second-hand from his wife.

The Angel does not answer Manoah's questions about the child, but again emphasises how the woman must behave during her pregnancy (13:14): Once again a bit wilful? The writer uses "challenge-reaction-communication" to persuade the intended readers/listeners to accept a more positive depiction of Manoah's wife and a more negative depiction of Manoah. Why? The Angel (which later appears to be the LORD Himself) subtly challenges the conventional views and customs. ${ }^{21}$

Manoah offers "the man" food to eat, but the Angel refuses it (cf. 13:15-23). Manoah still does not accept that it is the Angel of the LORD that is speaking to him and asks "the man" his name (13:17). It is only when the LORD makes the miracle happen that Manoah realises who he is dealing with. His immediate reaction is to conclude that they will die because they have seen God, but his wife reassures him (13:21-23). In contrast with what we might expect, the writer portrays Manoah in a negative light and his wife in a positive light. The woman "has knowledge" of God, Manoah "does not have such knowledge". The writer again creates tension by juxtaposing Manoah and his wife here. Owing to her lowly position in society and her barrenness, his wife has learnt to seek refuge in the LORD, to seek his presence while alone (in the field) and to trust in God unconditionally. The writer uses this technique in the text to focus the reader/listener's attention on the hidden message (cf. Amit 2000:95).

Chapters 13:15-23 and 6:19-23 share a traditional pattern (cf. also Gen 18:4-8, where the "three men" appeared to Abraham and Sarah). ${ }^{22}$ As with any good MiddleEasterner, Manoah knows the correct procedure (to show hospitality) to retain a man's

21 God and Manoah's wife deal with the issue of the birth of the son and the future of the heroic child exactly as in similar Bible announcements (cf. 1 Sam 1:1-28; Luke 1:46-54; see footnote 13).

22 There are various forms in which the divinity is represented in the Hebrew Bible (e.g., angels, one man, three men; cf. Gen 18:4-8). The meaningful ambiguity of the different representations is important for understanding the Israelites' view of the role and nature of the divinity (Kugel 2003). The Israelite writer thus makes provision for the divinity's inexplicable, complex behaviour and actions. 
goodwill: give your guest food to eat (see also Gideon's account in Chapter 6, which is very similar).

The woman "sees" the supernatural, awe-inspiring figure, but her husband does not "see" him yet (because he offers him food to eat). One of the most important elements in the account of Manoah and his wife is precisely that she has a spirit of discernment to perceive and evaluate things spiritually. As mentioned previously, the juxtaposition of ideal and non-ideal bodies creates tension, and the purpose is to compare opposing ideological systems and thus highlight the rhetoric (van der Merwe 2009).

The special divine identity of the visitor becomes evident when "the Angel" indicates that he will not eat Manoah's food (13:16). We get the impression that the Angel will not let himself be manipulated by Manoah. It is not clear why this is so, but perhaps the Angel of the LORD knows more about Manoah than is revealed in the text and the writer wishes to convey a message subtly. The Angel will only allow Manoah to present a burnt offering to the LORD. ${ }^{23}$ This does not necessarily mean that the "Angel" distinguishes himself from the LORD (Cundall 1968:159). Implicitly, he actually gives Manoah an indication that he is not flesh and blood. Therefore, the Angel is not a person who needs to be fed.

Manoah's behaviour is excused (by the narrator) by stating that he did not know that it was the "Angel of the LORD" (3:6), but the reason for the Angel's attitude towards Manoah is probably concealed in this statement. He has no sense or insight into what is happening to them - no wonder the Angel of the LORD chooses to speak to his wife instead. It is noteworthy that later in the account, the LORD displays much more patience with Samson than with his father, Manoah.

Despite the fact that "the man" declines Manoah's offer to eat with them, Manoah still believes that he can gain an opportunity to ask more questions (13:17). Manoah asks the man his name so that they can honour him when the promise of the "Angel" comes true. It was believed that if someone knew your name, they could control or exercise authority over you.

23 A burnt offering means that everything on the altar is consumed by fire. 
The "Angel of the LORD" sees through Manoah (13:18). Manoah is sceptical; he wants to know, he wants answers and he is not easily satisfied. For the umpteenth time, the Angel ignores Manoah's request. He does not give his name because, according to the Angel, it is too "wonderful", in other words, too difficult (פלאי, a term that is also used in the Song of Miriam in Exodus 15:11 and an indication of God's miraculous activities) for Manoah to pronounce or comprehend (Matthews 2004:142). ${ }^{24}$

The repeated requests for confirmation are no different from the requests for signs in the case of the uncertainty of Moses (Exod 3:11; 4:1) or Gideon (Judges 6:36-40; 7:9-15) (Niditch 1990:145). In this context, the question motif serves to contrast the uncertain, uninformed man with his calm, wise wife (cf. in this regard also Deborah and Barak in Judges 4-5).

Presenting an offering was a sign of honour, respect and worship. Manoah therefore takes the "Angel's" advice (13:16) to present a burnt offering to the LORD (13:19) instead. Manoah wants to prepare a young goat for the man. ${ }^{25}$ But Manoah still fails to "perceive" that it is an Angel of the LORD (cf. Gideon in 6:22; Amit 2000:148, n 50). The "seeing" (ראה) motif is common to all accounts of divine appearances.

Apart from the pregnancy, a second miracle occurs before their eyes while both are looking on (13:20). The flame ascending from the altar is often a symbol of the power and presence of the divinity (Gen 15:17; Exod 3:1-6; Judg 6:19-23) and usually takes the Angel of the LORD (or the messenger) heavenward. This miracle therefore confirms who the person was that they had been dealing with. As a result of this confirmation, Manoah and his wife fall with their faces to the ground in worship (cf. 1 Kings 18). Only then does Manoah realise that it was the Angel of the LORD

24 The name of the divinity is made known only in exceptional cases (cf. Abraham and Moses in Gen 15:7; Exod 3:13-14; 6:2). The name of the LORD (his nature) is actually too wonderful for anyone to comprehend (Harris et al. 2002:222).

25 The young goat is intended for the burnt offering and the grain offering usually consisted of grain, oil and flour, which were shaped into a cake and offered on the altar along with the burnt offering (cf. Lev 2). 
that had appeared to him (13:21). The Angel never appears to Manoah and his wife again.

In the midst of the miracle that takes place before their eyes, Manoah's account reminds one of Jephthah and Samson's conduct: he thinks only of himself and his own interests (Ackermann 1998:112). Manoah's concern that they will "surely die" because they have seen "God" (no longer just the "Angel of the LORD") reflects a tradition that occurs elsewhere in the Old Testament (cf. Gen 32:30; Exod 33:20). There was a belief that if you saw God, you would certainly die - which appears to be groundless in this instance. Manoah is panic-stricken and once again shows his ignorance of what had taken place there. His fear is completely out of proportion: contrary to the tradition, he needs his wife to interpret the events for him (13:23). He fails to recognise that his wife has seen "God" a few times already and has suffered no ill effects. It seems that the narrator's intention is precisely to contrast Manoah's behaviour with that of his wife.

Manoah's wife's behaviour is cool and calm and reminds one of the conduct of Jephthah's daughter (Chapter 12). She explains to her husband what has happened as if to a child: If the LORD had wanted to put them to death, he would not have accepted a burnt offering and a grain offering from their hand (verse 23). Here the "Angel" is referred to only as "the LORD" (Yahweh, the God of the Covenant). With spiritual eyes, she "sees" what is happening and shows theological insight. It was not the first time that the "Angel of the LORD" had appeared to her or that she had sought refuge in Him. She perceives the supernatural.

Manoah's wife gives birth to a son and the LORD blesses him: the Spirit of the LORD "started" to impel him (13:25). Upon the birth of the son, the promise of the LORD is fulfilled and the mother's status in society rises. Contrary to the existing system, it is clear that the mother named the child. In Egypt, a child acquired his/her name from the one exercising authority over the child - this could be the father or the mother (cf. Wilcke 1984:170-180). The child grows up and the LORD continues to bless him, as promised (13:24). 
Everything sounds very promising, although the word "started", which echoes verse 5 , should already alert readers. ${ }^{26}$ Perhaps the mother's faith was a blessing to her child. Perhaps the references $(13: 3,24)$ to the Spirit that "started to impel" Samson (ותחל) foreshadow what lies ahead in chapters 14-16. In these sections, it is the Spirit, rather than Samson's status as a Nazirite or his supernatural birth, that fills him with power (Brettler 2002:43).

The reference to the "camp of Dan" is interesting because it indicates a temporary settlement. This situation was probably caused by pressure from the Amorites and the Philistines. Perhaps Samson's visits to the camp of Dan (between Zorah and Eshtaol) ${ }^{27}$ made him feel troubled so that the Spirit of the LORD could prepare him for his intended role as judge and leader against the Philistines. The only way in which the guidance of the Spirit was evident in Samson's life was in his extraordinary physical strength $(14: 6,19 ; 15: 14)$. Unfortunately, he used this power only for his own personal gain and it also existed without the operation of the Spirit $(16: 3,30)$. His exceptional strength was related to the growth of his hair, in other words, to the fact that he was a Nazirite (Soggin 1981:229). ${ }^{28}$

26 As mentioned previously, Samson and his parents lived in the Philistine district or very close to the Philistines. They belonged to the tribe of Dan and Samson's actions occurred in the area of the traditional, alloted area of Dan. Up until this stage, the tribe of Dan had not yet taken possession of their tribal allotment (cf. Josh 19:47, 48). Instead of forcibly driving other groups (the people of Laish) out of their territory, they could have used Samson to take possession of their own tribal allotment (cf. Ch. 18). The fact that the Spirit of the LORD "started" (פעם) to impel him shows that he began to be sensitive to the leading of the Spirit, in the camp of Dan (mahane-dan), between Zorah en Eshtaol (cf. Samuel in 1 Sam 2:26 and Jesus in Luke 2:40, 52).

27 Between Zorah and Eshtaol (13:25) is mentioned again in the last part of this series of accounts - in 16:31 - which is where Samson was buried. Later it is mentioned again in $18: 2,8$ and 11, which suggests that Judges 13:25 not only integrates the introduction to the account of Samson, but also relates to the following account. This idea is emphasised by the reference to the "camp of Dan", which occurs again in 18:12. According to Brettler (2002:43), 13:25 was written after chapters 13-16, or even after chapters 13-18, and is an attempt to merge the different accounts.

28 The role of the Nazirites can be compared to the way of life of the Rechabites in Jeremiah 35 (Mondriaan 2010). 


\section{CONCLUSION}

Contrary to the convention, the nameless, barren woman is the one who is alert and is the intelligent doer in the account. The unconventional behaviour is used by the narrator to create tension and uncertainty. This technique serves the purpose of his/her writing, namely to advocate a countercultural ideology (cf. van der Merwe \& Coetzee 2009:683). Steinberg (1987:478-482) believes that the narrator uses the misplacement of conventional models in an attempt to create inequality and thus use rhetoric to communicate persuasively. The goal is to bring the reader/listener around to the writer or narrator's own point of view. In other words, the writer or narrator of Judges 13 is attempting, by means of shifts in his/her countercultural rhetoric, to persuade the readers/listeners that the non-ideal body (or differently functioning body) is more beneficial than the dominant ideology suggests.

"The woman", not Samson, is the role model of faith and is the one who is in tune with God and his word (13:23; more so than most judges). The use of irony and the paradoxical way in which the writer composes his/her account shows that both the writer's attitude and the text are polemical (LaCocque 1990:23, 28). Judges 13 serves as an illustration of a countercultural rhetoric that is used to replace the dominant ideology with an alternative ideology in which other and differently functioning bodies are not considered threatening, but as beneficial for society and culture (cf. van der Merwe \& Coetzee 2009:680; cf. Achsah, le Roux 2015:503-521).

Regarding the first criterion for a hidden polemic, there is no explicit indication in the text (of Judges 13) of an alternative ideology concerning the other and differently functioning bodies (cf. Amit 2000:94-97; le Roux 2015:515).

Secondly, the writer uses various techniques in the text to draw the reader's attention to the hidden polemic (cf. Amit 2000:95). This is done specifically in terms of the different bodies and the replacement of such bodies according to the dominant ideology. In Judges 13, the writer dismisses the dominant body ideology by using the technique of juxtaposition and replacement, thereby creating a paradox, uncertainty and irony (cf. le Roux 2015:515). 
The third criterion for the presence of a hidden polemic in the text is the existence of polemic on the same subject in other passages of the Bible. Despite the dominant cultural ideology, the roles of women in early Israelite households often extended beyond the boundaries of their household. Deborah served as a prophetess (Judges 4 and 5); Jephthah's daughter instituted an annual commemoration; Hannah went alone to the house of the LORD to worship, to offer a sacrifice and to make a vow to the LORD (1 Sam 1:1-28); and the prophetess Huldah is well known for her actions in 2 Kings 22:14-22 (Meyers 1998:256; cf. Frymer-Kensky 2006).

Fourthly, it was also not unusual in ancient Near Eastern texts for women to enjoy equal privileges, to be favoured by a higher Authority or to experience a divine appearance. On the contrary, this often happened to barren women. The theme of the goddess Anatu, who was barren, is well known in both Ugarit and in certain parts of Egypt (KTU 1.13, in te Velde 1967:28-29; cf. Marsman 2003:210) and motherhood was also highly esteemed.

The aim of the technique, therefore, is to challenge or polemicise the existing cultural perception or ideology (cf. van der Merwe \& Coetzee 2009:677-694). Therefore, the writer replaces the social status of the whole body in Judges 13 with a non-ideal body, namely "the wife of Manoah, the mother of Samson".

\section{BIBLIOGRAPHY}

Ackerman, S 1998. Warrior, dancer, seductress, queen. Women in Judges and biblical Israel. London: Doubleday.

Alter, R 1990. Samson without folklore, in Niditch 1990:47-73.

Amit, Y 1999. The book of Judges. The art of editing. Transl. J Chipman. Biblical Interpretation Series 38. Leiden: Brill. 2000. Hidden polemics in Biblical narrative. Transl. from the Hebrew by J Chipman. Biblical Interpretation Series 25. Leiden: Brill.

Berlin, A 1983. Poetics and interpretation of Biblical narrative. Bible and literature series. Sheffield: Almond.

Berquist, J L 2002. Controlling corporeality. The body and the household in ancient Israel. New Brunswick: New Jersey.

Blenkinsopp, J 1963. Structure and style in Judges 13-16, JBL 82:65-76.

Brenner, A \& Van Dijk-Hemmes, F 1996. On gendering texts: female and male voices in the Hebrew Bible. Biblical Interpretation Series I. Leiden: Brill. 
Brettler, M Z 2002. The book of Judges. Old Testament Readings. London: Routledge. Crenshaw, J L 1978. Samson: a secret betrayed, a vow ignored. Atlanta: John Knox.

Cundall, A E 1968. Judges. An introduction and commentary. Tyndale Old Testament commentaries. London: Tyndale.

Davies, P 1998. Scribes and schools: the canonization of the Hebrew scriptures. Library of ancient Israel. Louisville: Westminister.

Del Olmo Lete, G 1981. Le mythe de la vierge-mère 'Anatu: Une novelle interprétation de CTA/KTU 13, UF 13:50-58.

Exum, J C 1980. Promise and fulfillment: Narrative art in Judges 13, JBL 99:43-59. 1983. The theological dimension of the Samson saga. VT 33, 3-45. 1995. Feminist criticism: whose interests are being served? in Yee 1995:65-90.

Frymer-Kensky, T 2006. Studies in Bible and feminist criticism. JPS Scholar Distinction Series. Philadelphia: The Jewish Publication Society.

Gottwald, N K 1985. The Hebrew Bible - a socio-literary introduction. Philadelphia: Fortress.

Hamlin, E J 1990. At risk in the Promised Land. Edinburgh: Handsel.

Harris, G J, Brown, C A \& Moore, M S 2000. New international biblical commentary. Joshua, Judges, Ruth. Peabody: Hendrickson.

Herrmann, S 1981. A history of Israel in Old Testament times. London: SCM.

Klein, L 1988. The triumph of irony in the Book of Judges. Journal for the study of the Old Testament supplement series, 68. Sheffield: Almond.

Krebernik, M 1993-1997. 'Muttergöttin A.I, RLA Bd 8:502-516.

Kugel, J L 2003. The God of Old: inside the lost world of the Bible. New York: Free.

LaCocque, A 1990. The feminine unconventional: four subversive figures in Israel's tradition. Minneapolis: Fortress.

Le Roux, M 2015. Agsa, vrou van Otniël. JSem 24/2:503-521.

Lucas, D J, Galvin, J C, Veerman, D R \& Barton, B B 1984. Judges. A life application Bible study. Illinois: Tyndale.

Marais, K 2001. Rigters. Plek vir almal in God se plan. ’n Bybelstudie-reeks vir groepe of individue. Wellington: Lux Vebi.BM.

Marsman, H J 2003. Women in Ugarit and Israel. Their social and religious position in the context of the ancient Near East. Oudtestamentishe studiën. Leiden: Brill.

Matthews, V H 2004. Judges and Ruth. The New Cambridge Bible Commentary. Cambridge: University Press.

Matthews, V H, Levinson, B M \& Frymer-Kensky, T 2004. Gender and law in the Hebrew Bible and the ancient Near East. London: T \& T Clark.

McCann, J C 2002. Judges. A Bible commentary for teaching and preaching. Louisville: John Knox.

Meyers, C 1998. Everyday life: women in the period of the Hebrew Bible, in Newsom and Ringe 1998:251-262.

Mondriaan, M E 2010. The rise of Yahwism: role of marginalised groups. Unpublished PhD dissertation. Pretoria: University of Pretoria.

Newson, C and Ringe, S (eds) 1998. Women's Bible commentary. Louisville, Kentucky: Westminster John Knox.

Niditch, S 1997. Ancient Israelite religion. Oxford: University Press. (ed.) 1990. Text and tradition. The Hebrew Bible and folklore. Atlanta: Scholars.

Reinhartz, A 1998. Samson's mother: An unnamed protagonis, JSOT 77:27-38.

Roth, M T 1995. Law collections from Mesopotamia and Asia Minor. WAW 6. Atlanta:

Scholars. 
Soggin, J A 1981. Judges. OTL; transl. J Bowden. London: SCM.

Sternberg, M 1987. The poetics of biblical narrative: ideological literature and the drama of reading. Bloomington: Indiana University Press.

Te Velde, H 1967. Seth, God of confusion: A study of his role in Egyptian mythology and religion. $\mathrm{P} \ddot{\mathrm{A}}, 6$. Leiden: Brill.

Van der Merwe, N C 2009. The identification of whole and unwhole bodies in the book of Judges. Unpublished DLitt et Phil dissertation. University of Johannesburg.

Van der Merwe, N C \& Coetzee, J H 2009. An alternative ideology relating to difference as hidden polemic in the book of Judges: Judges 4-5 as an illustration, OTE 22/3:677-694.

Wilcke, C 1984. CT 45, 119: Ein Fall legaler Bigamie, ZA 74:170-180.

Yee, G A (ed.) 1995. Judges and method. New approaches in biblical studies. Minneapolis: Fortress. 